\title{
STRATEGI PENGEMBANGAN EKOWISATA DI TAMAN NASIONAL KELIMUTU
}

\author{
Ecotourism Development Strategy in Kelimutu National Park
}

\author{
Rudi Hermawan ${ }^{1}$, Arief Chandra ${ }^{2}$, dan Persada Agussetia Sitepu ${ }^{3}$ \\ ${ }^{1}$ Fakultas Kehutanan, Universitas Nusa Bangsa, Jl. Sholeh Iskandar No. 4, Bogor, \\ Jawa Barat. \\ ${ }^{2}$ Peneliti di PT Perencana Indah Engineering, RT 012, RW 005, Kelurahan Liliba, \\ Kecamatan Oebobo, Kupang, NTT. \\ ${ }^{3}$ Kepala Balai Taman Nasional Kelimutu, Jl. Eltari, No. 16, Kel. Paupire, Ende, NTT. \\ Email: rudihermawanipb@gmail.com
}

\begin{abstract}
Ecotourism development strategy in Kelimutu National Park (KNP) is very necessary because KNP has enormous potential for ecotourism development. The potential is either in the form of flora, fauna, geology, environmental beauty, and cultural potential of the surrounding community. The aims of this study are to know the right strategy in ecotourism development and determine the priority scale of ecotourism pathways development in KNP. This study uses a case study approach. Data were collected through in-depth interviews of KNP management, stakeholders in the management of ecotourism of KNP, communities around KNP, and observation. The data were analyzed using stakeholders analysis to determine the stakholders that involved on ecotourism management in KNP, SWOT (Strength, Weakness, Opportunities, Threats) analysis to determine the right strategy in ecotourism management, and AHP (Analysis Hierarcy Process) to determine the priority scale of ecotourism development from several ecotourism pathway in KNP. The results show that the most appropriate strategy in the development of ecotourism in KNP is offensive strategy (taking advantage of opportunities and strengths owned), and ecotourism pathway that get the first priority to be developed is the Moni Pathway, the second is Wologai Pathway, the third is Sokoria Pathway, and the fourth is Niowula Pathway.
\end{abstract}

Keywords: Kelimutu National Park,Ecotourism, Strategy, Development.

\begin{abstract}
ABSTRAK
Strategi pengembangan ekowisata di Taman Nasional Kelimutu (TNK) sangat diperlukan karena TNK memiliki potensi yang sangat besar untuk pengembangan ekowisata. Potensi tersebut baik berupa flora, fauna, geologis, keindahan lingkungan, dan potensi budaya masyarakat sekitar. Tujuan penelitian ini adalah untuk mengetahui strategi yang tepat dalam pengembangan ekowisata dan menentukan skala prioritas pengembangan lokasi ekowisata di TNK. Penelitian ini menggunakan pendekatan studi kasus. Data dikumpulkan melalui wawancara mendalam terhadap pengelola TNK, para pihak terkait pengelolaan ekowisata TNK, masyarakat sekitar TNK, serta observasi. Data dianalisis dengan menggunakan analisis parapihak (stakeholder) untuk menentukan parapihak yang terlibat dalam pengelolaan ekowisata di TNK, analisis SWOT (Strength, Weakness, Opportunities, Threats) untuk menentukan strategi yang tepat dalam pengelolaan ekowsiata, dan AHP (Analysis Hierarcy Process) untuk menentukan skala prioritas pengembangan areal ekowisata dari beberapa areal ekowisata ada di TNK. Hasil penelitian menunjukkan bahwa strategi yang paling tepat dalam pengembangan ekowisata di TNK yaitu strategi ofensif (memanfaatkan peluang dan kekuatan yang dimiliki), serta areal ekowisata yang mendapat perioritas pertama untuk dikembangkan yaitu areal Moni, ke dua yaitu areal Wologai, ke tiga yaitu areal Sokoria, dan ke empat yaitu areal Niowula.
\end{abstract}

Kata kunci: Ekowisata, Taman Nasional Kelimutu, Strategi, Pengembangan. 


\section{PENDAHULUAN}

Taman Nasional Kelimutu (TNK) merupakan hasil perubahan fungsi dan penggabungan dari Cagar Alam Danau Kelimutu dan Taman Wisata Kelimutu di Kabupaten Ende, Propinsi Nusa Tenggara Timur melalui Keputusan Menteri Kehutanan SK No: 279/Kpts-II/1992 tanggal 26 Februari 1992, seluas 5.000 ha (TNK, 2012). Hasil pengukuhan kawasan TNK sesuai tata batas 1984 diperoleh luasan TNK yaitu 5.356,50 ha yang ditetapkan dengan Keputusan Menteri Kehutanan No: 679/Kpts-II/1997 tanggal 10 Oktober 1997 (TNK, 2012). Berdasarkan luasan tersebut maka garis batas TNK yaitu 48.423,33 meter. Secara administratif, TNK terletak di Kabupaten Ende, dikelilingi oleh lima kecamatan, yaitu Kecamatan Detusoko, Kecamatan Kelimutu, Kecamatan Wolojita, dan Kecamatan Ndona Timur, dan Kecamatan Ndona.

Kawasan TNK memiliki kekayaan flora dan fauna, serta jasa lingkungan yang beragam. Kekayaan flora digambarkan dengan adanya jenis flora sekitar 100 jenis dalam 36 famili, yang di antaranya ada jenis endemik seperti Uta Onga (Begonia kelumuensis) dan Turuwara (Rhododendron renschianum), serta jenis lainnya; dan kekayaan fauna yang tidak kurang dari 4 jenis mamalia dan 19 jenis burung (TNK 2009; TNK 2016; TNK 2015; Watu 2017). Danau Tiga Warna atau Danau Kelimutu memiliki potensi jasa lingkungan untuk dikembangkan sebagai ekowisata. Danau tersebut terbagi menjadi tiga danau, yaitu Danau Ata Mbupu, Danau Nua Muri Koo Fai, dan Danau Atapolo. Alam dan adat budaya masyarakatnya dapat dikembangkan menjadi ekowisata yang unik dan memiliki daya tarik yang khas baik untuk skala domestik maupun mancanegara.

Potensi ekowisata di TNK belum dikembangkan secara optimal. Potensi ekowisata tersebut yaitu terkait atraksi, akses, dan amenitas. Jika ketiga aspek potensi tersebut (atraksi, akses, dan amenitas) telah berkembang optimal maka hasil dari ekowisata akan lebih terasa oleh semua pihak yang terlibat dalam pengelolaan TNK yang berbasis kelestarian aspek ekologi, ekonomi, dan sosial. Salah satu cara untuk mengoptimasi potensi aspek ekowisata di TNK yaitu dengan cara menyusun strategi pengelolaan yang tepat. Penelitian ini bertujuan mengetahui strategi yang tepat dalam pengembangan ekowisata di TNK dan penentuan skala prioritas pengembangan jalur ekowisata di TNK. Adapun manfaat dari penelitian ini adalah sebagai bahan pertimbangan dalam upaya pengembangan ekowisata di TNK sesuai dengan potensi sumber daya yang dimiliki pihak pengelola TNK sebagai pihak internal maupun oleh masyarakat sekitar dan atau wisatawan sebagai pihak eksternal.

\section{METODE}

Penelitian bertempat di Zona Pemanfaatan TNK, Kabupaten Ende. TNK yang terletak pada ketinggian 1600 meter di atas permukaan laut (mdpl) memiliki tiga buah danau, yaitu Danau Ata Mbupu, Danau Nua Muri Koo Fai, dan Danau Atapolo. Seluruh danau tersebut merupakan bekas letusan Gunung Api Kelimutu yang hingga saat ini menyisakan sejarah, misteri, dan keajaiban alam. Hingga saat ini, dari letusan Gunung Api Kelimutu tersebut telah mempengaruhi sosial budaya masyarakat sekitarnya yang dituangkan dalam legenda kehidupannya.

Penelitian dilaksanakan selama Juli - September 2017. Alat dan bahan yang digunakan dalam penelitian yaitu alat tulis, kamera, GPS receiver, dan kuesioner. Metode pengumpulan data melalui beberapa tahap yaitu studi literatur, observasi lapang, dan wawancara. Data yang diperoleh kemudian dianalisis menggunakan metode analisis parapihak (stakeholder), analisis SWOT (Fahmi, 2015), dan AHP (Saaty, 1993).

Metode analisis parapihak dilakukan dengan cara mengumpulkan data dan informasi terkait parapihak yang terlibat secara langsung atau tidak langsung dalam pengelolaan TNK. Batasan parapihak yaitu masyarakat lokal, sektor swasta, dan pemerintah (Tania, 2016). Data dan informasi parapihak tersebut diperoleh melalui wawancara dengan pihak internal (pengelola TNK) dan pihak eksternal (pemerintah daerah setempat, tokoh masyarakat, dan Lembaga Swadaya Masyarakat (LSM). Metode anaisis SWOT digunakan untuk 
mengkelasifikasikan faktor internal dan ektsternal. Faktor internal tersebut kemudian dirinci dan dikelaskan sehingga menjadi dua kelas, yaitu kelas kekuatan (strength) dan kelas kelemahan (weakness). Proses selanjutnya yaitu perincian dan pengkelasan faktor eksternal menjadi kelas ancaman (threat) dan peluang (opportunity). Berbeda dengan metode analisis SWOT, metode AHP (Analysis Hierarcy Process) merupakan lanjutan dari analisis SWOT. Dengan analisis AHP tersebut maka faktor yang ada pada hasil analisis SWOT diurutkan berdasarkan skala prioritas. Urutan objek yang akan diurutkan berdasarkan skala prioritas ditentukan berdasarkan pertimbangan waktu, tempat, dan/ atau sumber pendanaan dalam pengembangan ekowisata oleh pengelola TNK. Dengan diketahuinya skala prioritas pada tiap objek yang dipilih maka pihak pengelola TNK akan lebih efektif dan efisien serta mendapat luaran yang optimal dari aksi-aksi yang telah dilakukan terhadap pengembangan ekowisata di TNK. Dari berbagai metode tersebut diharapakan mendapat strategi yang tepat bagi pengembangan ekowisata di TNK.

\section{HASIL DAN PEMBAHASAN}

\section{A. Potensi Pengunjung}

Kelas umur pengunjung cukup beragam, yaitu dari kelas umur anak-anak hingga tua. Selain itu, jumlah pengunjung di TNK mengalami kenaikan setiap tahun baik dari wisatawan domestik (wisdom) maupun mancanegara (wisman) (Gambar 1).

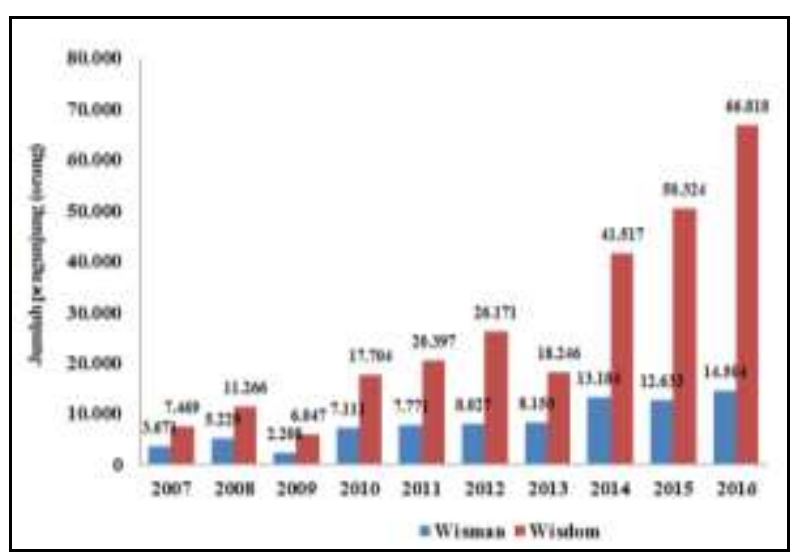

Gambar 1 Jumlah pengunjung selama 10 tahun terakhir di TNK.

Figure 1 The total of tourist along 10 years at KNP.

Motivasi pengunjung datang ke TNK paling besar yaitu tertarik dengan adanya Danau Kelimutu $(10,84 \%)$, sedangkan yang paling sedikit diminati yaitu objek wisata satwa (fauna) sebesar 7,67\% (Gambar 2).

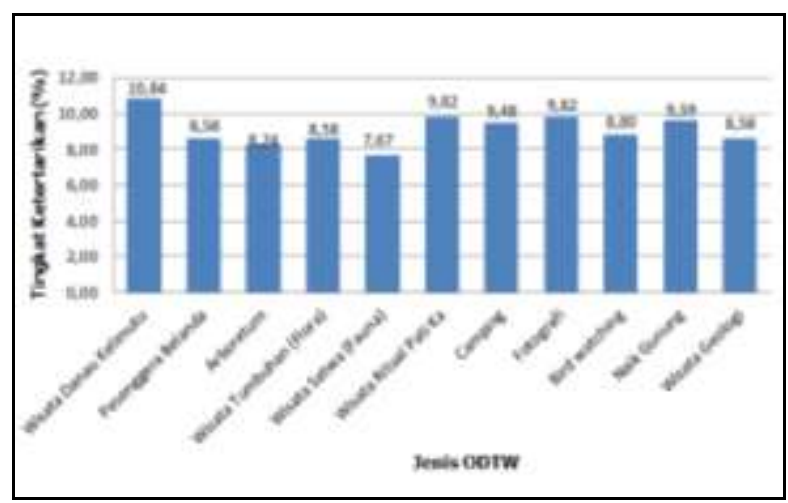

Gambar 2 Tingkat ketertarikan pengunjung pada objek wisata yang ada di TNK.

Figure 2 The stage of tourists to the objects tour at KNP. 


\section{B. Potensi SDM dalam Pengelolaan TNK}

TNK merupakan kawasan pelestarian alam yang dikelola langsung di bawah Kementerian Kehutanan dan Lingkungan Hidup. TNK dilengkapi oleh SDM dengan jenjang PNS dan Non-PNS. SDM yang telah PNS sebanyak 43 orang (Tabel 1). SDM TNK tersebar pada berbagai lokasi kerja, yaitu di kantor Balai TNK, di Kota Ende, di wilayah Seksi Pengelolaan Taman Nasional (SPTN) I dan SPTN II, serta di empat resort (Resort Detusoko, Resort Ndona, Resort Ndona Timur, Resort Wolojita, dan Resort Kelimutu).

Tabel 1 SDM menurut golongan di TNK

Table 1 Human resources at KNP

\begin{tabular}{clrrr}
\hline No. & \multicolumn{1}{c}{ Jenis Jabatan } & L & P & Total \\
\hline 1. & Struktural & & & \\
& a. Eselon III-A & 1 & 0 & 1 \\
& b. Eselon IV-A & 3 & 0 & 3 \\
2. Fungsional Umum & 11 & 3 & 14 \\
3. Fungsional Tertentu & & & \\
& a. Polisi Kehutanan & 10 & 2 & 12 \\
b. Pengendali Ekosistem Hutan & 10 & 0 & 10 \\
c. Penyuluh Kehutanan & 1 & 1 & 2 \\
d. Pranata Komputer & Jumlah & 1 & & $\mathbf{4 3}$ \\
\hline
\end{tabular}

Sumber: Laporan semester kepegawaian TNK, 2017.

SDM tersebut dilengkapi juga dengan SDM di luar TNK yang memiliki kepentingan terhadap pengembangan ekowisata di TNK (stakeholder), yaitu:

1. Dinas Pariwisata. Kemitraannya belum berjalan optimal terutama dalam hal kesinambungan antara atraksi, akses, dan akomodasi antara obyek wisata di TNK dengan obyek wisata lainnya yang ada di Kabupaten Ende;

2. Masyarakat sekitar yang berdekatan dengan Danau Kelimutu (Kecamatan Kelimutu) maupun yang jauh dari Danau Kelimutu (di Kota Ende) sebagai pengrajin souvenir, oleholeh khas, kuliner, penginapan, yang keseluruhannya belum berjalan optimal. Souvenir masih dikirim dari luar Ende dan terbuat dari bahan yang kurang berkualitas;

3. Swisscontact merupakan implementasi hasil kerjasama antara Pemerintah Swiss dengan Republik Indonesia, khususnya Departemen Kebudayaan dan Pariwisata RI dalam pengembangan pariwisata Flores. Hasil Swisscontact tersebut berupa terbentuknya dan berfungsinya DMO (Detination Management Organization) Regional Flores. DMO Flores itu sendiri merupakan titik simpul TMO (Tourism Management Organization) yang berada di setiap kabupaten di Flores, di antaranya di Kabupaten Ende;

4. BMKG yang menjadi sumber data seismograf bagi pengelola TNK sehingga bisa memprediksi aktifitas Danau Kelimutu dari data tersebut;

5. Mitra Tanggap Darurat yang masih kekurangan dalam hal koordinasi dengan pihak TNK; dan

6. Masyarakat adat atau komunitas adat yang biasa melakukan upacara adat di tiap desa dan upacara adat gabungan tahunan pada tiap tanggal 12 dan 14 Agustus. Terdapat sekitar 20 komunitas adat yang berada di sekitar TNK, di antaranya yaitu Komunitas Adat Puutuga, Koagata, Aesira, Saga, Ndito, Wolofeo, Detusoko, Wologai, Koanara, Tana Mau Nggadho, Pemo, Tenda, Mbuja, Wologeru, Roga Ria, Sekolengo, Meko Leja, Nuanoka, Jendo Laki, dan Niowula (Watu 2017).

\section{Objek wisata di Taman Nasional Kelimutu}

Objek wisata yang ada di TNK yaitu wisata Danau Kelimutu, Pesenggera Belanda, arboretum, wisata flora, wisata fauna, camping ground, fotografi, bird watching, naik gunung (hikking), wisata geologi, serta panorama sunset dan sunrise. Ada pun daya tarik wisata terkait masyarakat adat yaitu adanya upacara ritual adat Pati Ka Ata Mata atau Pati Ka Du'a Bapu Ata Mata (memberi makan kepada arwah leluhur) (Watu, 2017) yang merupakan upacara adat memberi makan bagi arwah leluhur atau orang yang telah meninggal. Adanya 
upacara ritual adat Pati Ka Du'a Bapu Ata Mata diharapkan terdapat tiga hal yang harus mendapat perhatian penting untuk mendukung keberadaan [ekowisata] Kelimutu yaitu menjaga budaya lokal, menjaga kelestarian alam terutama jenis burung endemik yang terancam punah, dan pengembangan menjadi daerah wisata untuk peningkatan ekonomi masyarakat (Watu 2017).

Selain itu masih terdapat juga objek wisata lain yang menarik di sekitar TNK yaitu rumah adat Suku Lio, kesenian tari adat Suku Lio yang ditayangkan selama prosesi ritual upacara adat Pati Ka Ata Mata, dan pertunjukan alat musik Sato.

\section{Fasilitas Layanan}

Fasilitas layanan ditujukan untuk menjamin kenyamanan pengunjung. Kenyamanan bisa diperoleh pengunjung di TNK dengan kualitas udara yang bebas bau, udara sejuk, bebas gangguan lalulintas, serta bebas gangguan manusia. Kenyamanan tersebut bisa diindikasikan dari minimnya/tidak adanya gangguan yang dialami oleh pengunjung (Ramli, 2011). Untuk mendukung kenyamanan pengunjung, maka pihak pengelola TNK telah menyediakan beberapa jenis fasilitas bagi wisatawan.

Fasilitas yang ada dapat dikelompokkan berdasarkan jalur wisata yang ada, yaitu Jalur Moni, Jalur Wologai, Jalur Sokoria, dan Jalur Niowula. Fasilitas yang paling lengkap yaitu di Jalur Moni. Fasilitas tersebut yaitu adanya parkiran kendaraan, loket pemungutan karcis masuk, pedagang makanan dan minuman, pedagang souvenir (kain selendang, sarung, ikat kepala khas Ende dan Flores, $T$-shirt khas TNK, aksesories pribadi), toilet (ada di sekitar gerbang SPTN Moni, parkiran atas, dan sekitar Danau Kelimutu), papan interpretasi (terkait kekayaan flora, fauna, dan kondisi geologis), papan larangan (larang berburu, larangan membuang sampah sembarangan, larangan melintas ke dalam danau), pagar pembatas areal upacara adat Pati $\mathrm{Ka}$, pagar pembatas dan pengaman bagi pengunjung yang terpasang sepanjang tanngga pendakian di bibir Danau Kelimutu, dan areal berkemah (tetapi tidak terurus). Fasilitas yang ada di Jalur Wologai yaitu gerbang masuk areal TNK, dan jalur jalan yang berupa jalan menuju kampung penduduk Desa Wologai kemudian disambung dengan jalan setapak. Fasilitas yang ada di Jalur Sokoria dan Niowula yaitu jalur berupa jalan setapak serta beberapa titik tertentu sebagai lokasi ritual adat masyarakat desa sekitar jalur tersebut.

\section{E. Analisis SWOT}

Berdasarkan penilaian terhadap masing-masing faktor (kekuatan, kelemahan, peluang, dan ancaman) maka disusun tabel IFA (Internal Factors Analysis) dan tabel EFA (External Factors Analysis). Tabel IFA dan EFA menyajikan hasil perhitungan antara bobot, nilai, dan jumlah (bobot $x$ nilai) disajikan pada Tabel 1.

Tabel 2. IFA (Internal Factors Analysis) dan EFA (External Factors Analysis). Table 2. IFA (Internal Factors Analysis) dan EFA (External Factors Analysis).

\begin{tabular}{clc}
\hline No. & \multicolumn{1}{c}{ Faktor } & Jumlah (Bobot x Nilai) \\
\hline 1 & Kekuatan (Strength) & 3,7568 \\
2 & Kelemahan (Weakness) & 3,0394 \\
3 & Peluang (Oportunities) & 3,4797 \\
4 & Ancaman (Threats) & 3,2133 \\
\hline
\end{tabular}

Berdasarkan tabel IFA dan EFA dapat diketahui nilai perhitungan antara faktor internal dengan faktor eksternal yang selanjutnya dapat diketahui strategi yang tepat. Proses penghitungan nilai faktor internal dan eksternal adalah sebagai berikut:

Faktor Internal $=$ Kekuatan - Kelemahan $=3,7568-3,0394=0,7174$ (dibulatkan menjadi 0,7)

Faktor eksternal $=$ Peluang - Ancaman $=3,4797-3,2133=0,2664($ dibulatkan menjadi 0,3$)$

Berdasarkan hasil perhitungan faktor internal dan eksternal yang positif, maka kondisi pengembangan ekowisata di TNK dalam keadaan baik. Jika dilihat dari posisi (quadran) koordinat yang dihasilkan antara nilai internal dan eksternal, maka berada pada posisi 
(quadran) I (X=0,7 dan $Y=0,3)$. Hal tersebut bermakna bahwa strategi yang tepat digunakan untuk pengembangan ekowisata di TNK yaitu strategi "ofensif" (Strategi S-O).

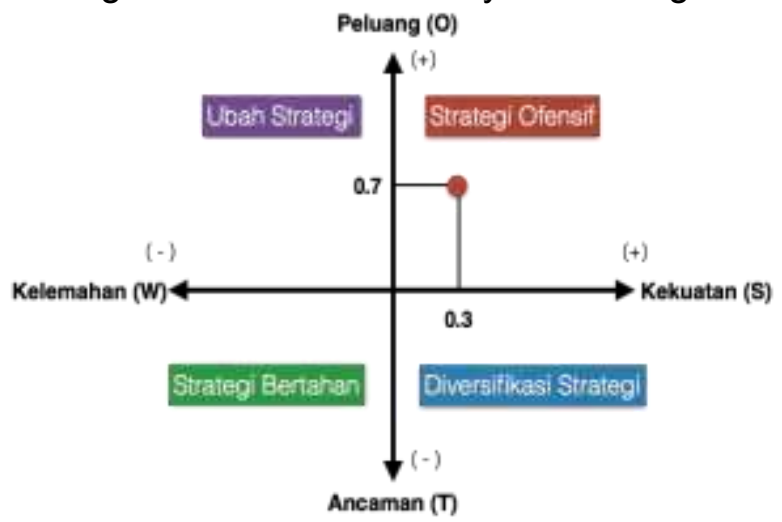

Gambar 3. Analisis SWOT ekowisata Taman Nasional Kelimutu.

Figure 3 SWOT analysis at KNP ecotourism.

Strategi ofensif yaitu memanfaatkan secara optimal peluang (oportunity) dan kekuatan (strength) yang ada. Faktor-faktor peluang dan kekuatan tersebut yaitu:

1. Melakukan kegiatan sosialisasi dan promosi paket ekowisata kepada masyarakat luas dan manca negara melalui media dalam jaringan (online) seperti internet (media sosial, website, blog); dan media cetak (offline) seperti brosur, leaflet, banner, majalah, koran, dan sebagainya.

2. Mengelola potensi obyek ekowsiata dengan memanfaatkan kooperatifitas Dinas Pariwisata Kabupaten Ende dengan instansi lain untuk mengembangkan obyek-obyek wisata lain searah dengan destinasi ekowisata TNK. Terkait destinasi maka Tarasionak 2014) menyatakan bahwa hal yang paling penting terkait pendekatan destinasi dalam praktek ekowisata adalah destinasi merupakan subjek untuk bersaing dan sebagai objek bisnis yang strategis.

3. Berusaha untuk memanfaatkan dukungan dan keterlibatan masyarakat sekitar/lokal, forum adat dengan stakeholder lainnya dalam penyusunan konsep ekowisata secara holistik.

4. Memanfaatkan kepedulian, keterbukaan, keamanan, dan kenyamanan yang ada di sekitar masyarakat dalam kegiatan ekowisata untuk meningkatkan jumlah pengunjung ekowsisata baik domestik maupun mancanegara.

5. Membuka dan/ atau meningkatkan lapangan pekerjaan terkait peluang usaha kuliner, peginapan (hotel, cottage, dsb), dan kerajinan tangan (handicraft) dan kesenian khususnya dari masyarakat sekitar TNK.

6. Mempercepat pembuatan akses yang menghubungkan antara objek daya tarik wisata satu dengan lainnya yang ada di kawasan ekowisata TNK

7. Pengembangan obyek wisata alam lainnya dalam kawasan dengan dukungan finansial dari pemerintah pusat dan donasi masyarakat internasional, terkait dengan pelestarian sumberdaya alam dan lingkungan di TNK secara khsus, dan kawasan konservasi lain secara umum.

8. Mendorong pengembangan pariwisata yang berkontribusi pada konservasi lingkungan dan budaya.

9. Mengembangkan fasilitas ekowisata yang se-alami/se-natural mungkin, berdampak rendah terhadap budaya, lingkungan, hemat penggunaan SDA, dengan menggunakan teknologi tepat guna. Adanya ekowisata akan berpengaruh positif dan negatif terhadap keadaan sekitar. Liu dan Lu (2014) menjelaskan bahwa ekowisata ada dampak negatifnya terhadap penduduk asli setempat, dan dampak negatif juga terhadap budaya masyarakat maka dampak negatif secara ekonomi, budaya, dan lingkungan ekologi.

10. Membangun sistem pengelolaan destinasi pariwisata dengan kolaborasi multi pihak.

11. Mengembangkan sistem pemasaran yang inovatif sesuai target pasar yang ada serta memanfaatkan target pasar bebas ASEAN (MEA). 


\section{F. Analysis Hierarchy Process (AHP)}

AHP hanya difokuskan pada pembanguanan infrastruktur penunjang jalannya ekowisata di dalam areal TNK. Pembangunan infrastruktur tersebut akan berdasarkan pada jalur-jalur wisata potensial yang biasa digunakan oleh wisatawan. Jalur wisata potensial tersebut yaitu Sokoria, Moni, Wologai, Sokoria, dan Niowula. Jalur-jalur tersebut tidak akan dikembangkan secara berbarengan, tetapi dipilih jalur-jalur tertentu berdasarkan skala prioritas. Hal tersebut dilakukan karena adanya keterbatasan sumberdaya yang dimiliki oleh pengelola TNK. Pemilihan jalur ditentukan oleh beberapa faktor penentu, seperti jumlah pengunjung, kemudahan akses jalan, kemudahan akomodasi, dan atraksi yang dimiliki. Hal tersebut didasarkan pada penjelasan Menteri Pariwisata (2017 yang menyatakan di sebuah media televisi nasional dan Suryawan (2014) bahwa aspek penting dari suatu destinasi wisata ditentukan oleh "3A", yaitu atraksi, aksesibilitas, dan amenitas (akomodasi, rumah makan, pusat informasi, biro jasa perjalanan, pemandu, prasarana umum, dan/atau fasilitas umum). Lokasi yang layak menjadi prioritas hingga prioritas terakhir secara berutuan yaitu Moni, kemudian Wologai, Sokoria, dan terakhir Niowula (Gambar 4).

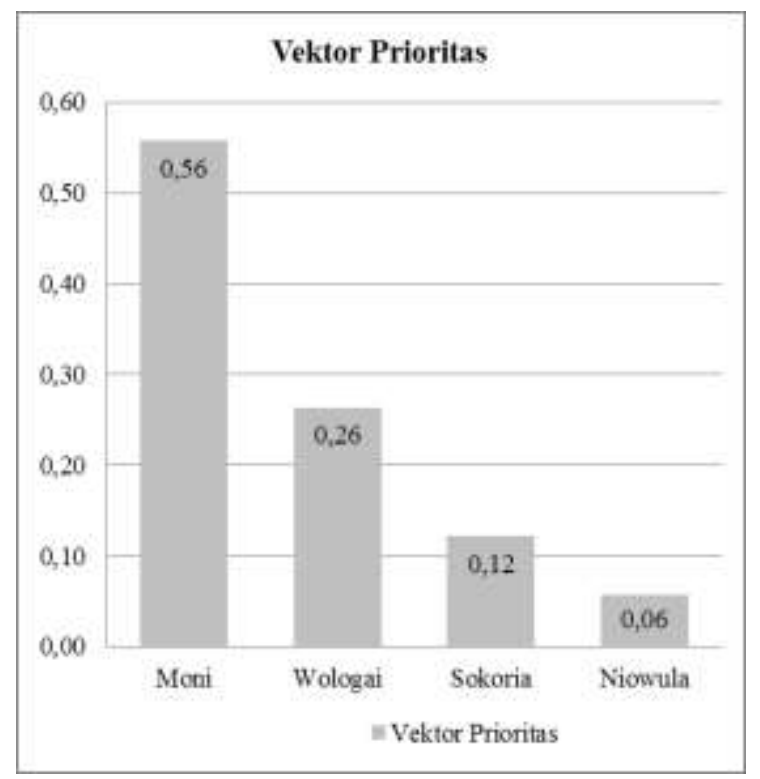

Gambar 4 Hasil analisis AHP.

Figure 4 Result of AHP analysis.

Jalur Moni merupakan jalur yang layak mendapat prioritas utama dikembangkan dibanding jalur lainnya. Faktor penentu skala prioritas pada tiap jalur yang akan dikembangkan diperhitungkan berdasarkan luasan areal yang sesuai untuk pengembangan areal ekowisata, atraksi yang dapat dilihat oleh pengunjung, kemudahan akses, kemudahan akomodasi, dan jumlah pengunjung yang memilih jalur tersebut. Berdasarkan faktor-faktor penentu tersebut jika diurutkan dari yang paling menentukan hingga yang kurang menentukan maka urutannya yaitu atraksi yang dapat dilihat oleh pengunjung $(0,29)$, jumlah pengunjung yang memilih jalur tersebut $(0,29)$, kemudahan akomodasi $(0,21)$, kemudahan akses $(0,12)$, serta luas areal yang sesuai untuk pengembangan areal ekowisata $(0,07)$.

Pengembangan ekowsiata pada kawasan TNK perlu mempertimbangkan pasokan (supply) dan permintaan (demand) ekowisata yang ada. Jika melihat data demand, maka kunjungan dari dalam maupun dari luar negeri mengalami peningkatan tiap tahun. Pengembangan ekowisata perlu dilakukan, terutama terkait akses, amenitas, dan atraksi ekowisata. Dilihat dari aspek akses, maka ekowisata TNK telah memiliki jalan yang baik untuk menuju jalur wisata Kawah Kelimutu, khususnya melalui jalur Ende - Moni. Jalannya telah beraspal dan bisa masuk berbagai jenis kendaraan untuk transportasi wisatawan. Sedangkan jalur lainnya, seperti jalur Wologai masih berupa bebatuan dan tanah, jalur Niowula dan Jalur Sokoria masih berupa jalan setapak sehingga dari jalur-jalur tersebut hanya memungkinkan dapat ditempuh dengan jalan kaki untuk mencapai lokasi Danau 
Kelimutu. Jalur Wologai, Niowula, dan Sokoria merupakan jalur yang hanya cocok untuk para wisatawan dengan minat khusus.

Berdasarkan pertimbangan amenitas, maka yang paling banyak penginapan yaitu jalur Moni. Meski demikian, perlu dilakukan penataan terkait keberadaan jasa penyedia penginapan. Penataan tersebut yaitu terkait supply penginapan yang harus disesuaikan dengan demand para wisatawan terhadap penginapan yang diinginkannya. Para wisatawan cenderung menginginkan penginapan dengan harga terjangkau, akses menuju lokasi wisata relatif dekat, pelayanan yang ramah, tempat yang bersih, tersedia akses infrmasi (telepon dan internet). Sejumlah pengunjung dari mancanegara, mereka menyatakan bahwa keberatan dengan adanya pelayanan akomodasi yang memberikan harga mahal terhadap para pengunjung baru atau pengunjung dari mancanegara. Dengan sikap pelayanan seperti itu maka wisatawan mancanegara memiliki kecenderungan tidak akan datang kembali ke kawasan wisata TNK secara khusus dan wisata-wisata lainnya yang ada di Ende dan Flores secara umum.

Wisman lebih cenderung tertarik menginap di Kota Ende meski jarak menuju objek Wisata Danau Kelimutu masih jauh, yaitu sekitar 1,5 jam kendaraan bermotor atau mobil. Terkait akomodasi, listrik dan air tidak menjadi masalah di sekitar TNK, karena listrik dan air telah masuk ke pemukiman penduduk dengan kualitas dan kuantitas normal.

Berdasarkan aspek atraksi maka TNK dan sekitarnya memiliki potensi objek daya tarik wisata yang unik dibanding daerah lain. Potensi ODTW yang unik tersebut secara keseluruhan belum dikelola dan belum terintegrasi satu sama lain. Seperti keberadaan Danau Kelimutu yang masih memerlukan penataan jika berkeinginan terintegrasi dengan kegiatan adat tahunan yang diadakan pada tiap tanggal 12 dan 14 Agustus. Kegiatan adat tahunan tersebut disebut dengan upacara adat Pati Ka. Pelaksanaan upacara adat Pati Ka atau Pati Ka Du'a Bapu Ata Mata berkaitan dengan tutur adat dan kehidupan sosial masyarakat yang meliputi Tedo Tembu, Wesa Wela (kesuburan tanah); Peni Nge, Wesi Nuwa (perkembangbiakan ternak secara lebih sehat dan cepat); Uja Mae Duna, Leja Mae Rapa (kemarau yang tidak panjang); Buru Mae Sepuu, Kaka Mae Sa Bege (kesehatan jasmani); dan Ju Mae Su, Pai Mai Lai (dijauhkan dari hama dan penyakit) (Watu 2017). Kegiatan upacara adat tersebut biasanya dihadiri oleh lapisan masyarakat adat dari berbagai desa yang ada di sekitar Danau Kelimutu hingga Bupati Ende.

Atraksi upacara adat di Danau Kelimutu perlu penataan, yaitu penataan terkait akses untuk para wisatawan sehingga dapat menyaksikan atraksi tersebut dari awal hingga akhir. Selama penelitian, maka hanya orang-orang tertentu yang dapat meliput atau melihat jalannya upacara puncak Pati Ka. Upacara puncak tersebut diadakan di sekitar batu tempat menaruh sesaji, sekitar Danau Kelimutu. Pada upacara puncak tersebut wisatawan lainnya tidak bisa meliput atau melihat secara penuh jalannya upacara karena adanya larangan/pembatasan, sehingga hanya boleh menyaksikan dari jarak jauh. Proses menyaksikan upacara puncak dari jarak jauh pun tidak optimal karena akses pandangan terhalang oleh pepohonan dan dan kontur lokasi upacara yang membatasi pandangan.

Berdasarkan aspek amenitas maka banyak hal yang perlu dikembangkan untuk menunjang pengembangan ekowisata di TNK. Upaya yang perlu dilakukan dalam pengembangan wisata di Kabupaten Ende secara umum dan ekowisata di TNK secara khusus yaitu pengembangan prasarana umum dan fasilitas umum, dan pengembangan fasilitas wisata (Suryawan 2014). Terkait souvenir maka berdasarkan hasil wawancara terhadap wisatawan mancanegara dan berdasarkan hasil observasi lapangan (pasar) maka souvenir yang ada masih terbatas ragamnya, bahan pembuatan masih kurang berkualitas, serta harga yang tidak bersahabat (sulit ditebak, pilih-pilih pembeli). Terkait dengan rumah makan atau restoran maka masih kurangnya pengembangan panganan atau menu khas lokal yang terjamin kualitasnya serta tempatnya yang nyaman, serta ramah pengunjung. Pengembangan amenitas ini harus tetap berorientasi pada tiga aspek kelestarian, yaitu ekologi, ekonomi, dan sosial. Untuk mencapai tiga kelestarian tersebut dari segi amenitas maka terkait juga dengan sarana. Sarana-sarana ekowisata harus tetap merupakan usaha kecil yang sepenuhnya berdasar pada perkekonomian setempat, tidak bisa menjadi 
sepenuhnya untuk keuntungan, serta harus menjadi sumber kebanggaan dan partisipasi lokal (Linberg 1993).

Selain atraksi, akses, dan amenitas, diperlukan juga aspek interpretasi. Interpretasi sangat perlu untuk kegiatan wisata karena dengan adanya interpretasi maka sesuatu yang biasa akan menjadi luar biasa jika telah diinterpretasikan. Terkait kegiatan interpretasi maka perlu dilakukan peningkatan jumlah dan kapasitas SDM. Jumlah interpreter yang memiliki potensi kapasitas untuk menginterpretasikan objek-objek wisata di TNK yaitu sebanyak empat orang. Potensi interpreter yang ada tersebut belum berjalan dengan baik karena masih menunggu permintaan baik dari pihak pengelola TNK maupun dari pihak pengunjung itu sendiri (wawancara lagsung terhadap Bapak Benediktus Rio Wibawanto sebagai staff TNK).

\section{KESIMPULAN DAN SARAN}

\section{A. Kesimpulan}

Strategi pengembangan ekowisata di TNK yang harus dilakukan yaitu strategi ofensif (memanfaatkan peluang dan kekuatan yang dimiliki). Skala prioritas dalam pengembangan jalur yaitu prioritas pertama Jalur Moni, prioritas ke dua Jalur Wologai, prioritas ke tiga Jalur Sokoria, dan prioritas ke empat Jalur Niowula.

\section{B. Saran}

Pengembangan ekowsiata di TNK perlu didukung dengan kegiatan interpretasi supaya kegiatan ekowsiata yang berjalan dapat memiliki manfaat optimal bagi pihak-pihak yang terlibat.

TNK diharapkan mampu menciptakan kesejahteraan baik bagi SDM pengelola TNK itu sendiri maupun bagi masyarakat adat sekitar TNK, serta aktif melibatkan masyarakat dalam kegiatan ekowisata di TNK; sehingga memungkinkan tercapainya prinsip pengembangan kepariwisataan yang berkelanjutan, yaitu kelestarian ekologi, kelayakan ekonomi, serta adil secara etika dan sosial.

\section{UCAPAN TERIMA KASIH}

Karya tulis dihasilkan atas kerjasama dan bantuan para pihak. Penulis mengucapkan banyak terima kasih kepada PT Perencana Indah Engineering (Ir. Luhut Manurung, MT), Manajemen TNK (B. Rio Wibawanto, S.Hut, MSi, dan staff lainnya), dan Dinas Pariwisata Kabupaten Ende (Drs. Derson Duka).

\section{DAFTAR PUSTAKA}

[TNK] Taman Nasional Kelimutu. (2009). Rencana Pengelolaan Jangka Panjang Taman Nasional Kelimutu Periode 2009 - 2029, Kabupaten Ende, Provinsi NTT. Ende: Taman Nasional Kelimutu.

[TNK] Taman Nasional Kelimutu. (2012). Statistik Balai Taman Nasional Kelimutu: Tahun 2008 - 2011. Ende: Balai Taman Nasional Kelimutu, Direktorat Jenderal Perlindungan Hutan dan konservasi Alam (PHKA), Kementerian Kehutanan.

[TNK] Taman Nasional Kelimutu. (2015). Laporan Pembuatan dan Pengamatan Petak ukur Permanen (PUP) Spesies Khas/Langka/Lokal/Khusus. Ende: Taman Nasional Kelimutu.

[TNK] Taman Nasional Kelimutu. (2015). Statistik Kelimutu: 2010 - 2014. Kementerian Kehutanan, Direktur Jenderal Perlindungan Hutan dan konservasi Alam (PHKA). Ende: Balai Taman Nasional Kelimutu.

[TNK] Taman Nasional Kelimutu. (2016). Monitoring Satwaliar Prioritas Burung Elang Flores (Nisaetus floris) Periode II di Kawasan Taman Nasional Kelimutu. Ende: Taman Nasional Kelimutu. 
Fahmi, I. (2015). Manajemen Strategis: Teori dan Aplikasi. Bandung: Alfabeta.

Laporan semester kepegawaian TNK. (2017). Data Excel Internal Taman Nasional Kelimutu. Ende: Tidak dipublikasi.

Lindberg, K. (2014). Ekoturisme: Petunjuk Untuk Perencanaan dan Pengelola. Jakarta: Privates Agencies Collaborating Together (PACT) dan Yayasan Alam Mitra Indonesia (ALAMI). Percetakan dalam bahasa Indonesia atas ijin dari penerbit The Ecotourism Society, North Benington, 1993.

Liu, TM. \& Lu, DJ. (2014). The Cultural and Ecological Impacts of Aboriginal Tourism: a Case Study on Taiwan's Tao tribe. SpringerPlus, 3:347. doi:10.1186/2193-1801-3-347. Diunduh dari http://www.springerplus.com/content/3/1/347.

Ramli, M., Muntasib, E.K.S.H., \& Kartono, A.P. (2011). Strategi Pengembangan Wisata di Pulau Bawean Kabupaten Gresik. Media Konservasi. 2012, 17 (2), 79-84.

Saaty, T.L. (1993). Pengambilan Keputusan Bagi Para Pemimpin. Proses Hirarki Analitik untuk Pengambilan Keputusan dalam Situasi yang Kompleks. Setiono L, penerjemah; Peniwati K, editor. Jakarta: PT Pustaka Binaman Pressindo. Terjemahan dari: Decision Making For Leaders. The Analitical Hierarchy Process for Decision in Complex World. Dalam Rangkuti 2011.

Suryawan, A.A.P.A., Budhi, M.K.S., Sukaatmadja, P.G., Mbete, A.M., Ardhana, I.K., Mochdar, D.F., Mesima, C., Radja, J.B., Murdaningsih, Sidyn, T.A.A., Eme, Y., Kerong, F.T.A., Nisanson, M.Y., Dhae, Rm.F. (2014). Rencana Induk Pengembangan Kepariwisataan Daerah Kabupaten Ende. Kerjasama Dinas Kebudayaan dan Pariwisata Kabupaten Ende dengan Pusat Kajian Bali Universitas Udayana. Denpasar: Pustaka Larasan.

Tania P. RB., Ralf C.B., Jason B. (2016). NGO Partnerships in Using Ecotourism for Conservation: Systematic Review and Meta-Analysis. PLOS ONE, 11 (11). doi:10.1371/journal.pone.0166919.

Tarasionak, A. (2014). Strategic Planning of Tourist Destinations: New Approach Towards Territorial Organization of Tourism in Belarus. Jurnal Geografijos Metraštis, 47, 25 - 36.

Watu, YDB. (2017, Juli). Agar Kawasan Taman Nasional Kelimutu Tetap Lestari. Tabloid Flobamora News: Suara Dari Timur, hlm. 7. Edisi 31/Tahun II/Juli 2017. 